\title{
The seashore sedges of the Russian Kola Peninsula: How many species?
}

\author{
Polina A. Volkova ${ }^{\mathrm{a}, \mathrm{b}, *}$, Alexey B. Shipunov ${ }^{\mathrm{c}}$, Reidar Elven ${ }^{\mathrm{a}}$, Christian Brochmann ${ }^{\mathrm{a}}$

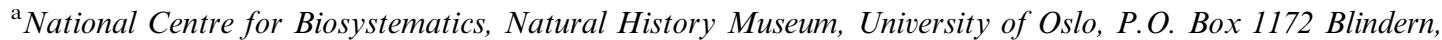 \\ NO-0318 Oslo, Norway \\ ${ }^{\mathrm{b}}$ Faculty of Biology, Department of Higher Plants, Moscow State University, Vorobyevy Gory, \\ Moscow 119899, Russian Federation \\ ${ }^{\mathrm{c}}$ College of Natural Resources, P.O. Box 441133, University of Idaho, Moscow, ID 83844-1133, USA
}

Received 21 May 2007; accepted 20 September 2007

\begin{abstract}
A necessary basis for environmental protection is thorough knowledge of the biodiversity to be protected. Setting conservation priorities in taxonomically complex groups is an especially difficult task. The seashore sedges of the Carex salina group (Cyperaceae) of the Russian White and Barents Seas form important parts of the coastal ecosystems and include species listed as rare and endangered. However, their taxonomy is poorly understood and supposed to be blurred by hybridization, also including the closely related $C$. aquatilis and possibly other species of sect. Phacocystis (C. bigelowii, $C$. nigra s. lat.). We address the taxonomic situation in the $C$. salina group in the Kola Peninsula with emphasis on taxa of supposed hybrid origin (C. salina and C. recta coll.). We analyzed 92 plants from 28 sites for 101 amplified fragment length polymorphisms (AFLPs) and 10 morphological characters. The plants referred to three supposedly "pure" species (C. aquatilis, C. paleacea and C. subspathacea) formed different extreme parts of the morphological and molecular variation. These species could be discriminated by a combination of morphological characters. The two taxa of proposed hybrid origin had extremely variable morphology and could not be clearly distinguished from each other or from the supposedly "pure" species. Our results demonstrate extensive gene flow between all taxa, suggesting that the entire $C$. salina group including $C$. aquatilis acts as a single large biological species.
\end{abstract}

(C) 2008 Elsevier GmbH. All rights reserved.

Keywords: AFLP; Morphology; Hybridization; Carex; Kola peninsula

\section{Introduction}

A necessary basis for environmental protection is thorough knowledge of the biodiversity to be protected. Such knowledge must be based on taxonomic

\footnotetext{
*Corresponding author at: Faculty of Biology, Department of Higher Plants, Moscow State University, Vorobyevy Gory, Moscow 119899, Russian Federation.

E-mail address: avolkov@orc.ru (P.A. Volkova).
}

investigations. It is, however, often problematic to distinguish closely related species belonging to "species complexes" or "critical groups". Setting conservation priorities in such taxonomically complex groups is especially difficult, in particular if hybridization is involved (Rieseberg and Gerber, 1995).

The sedges from the so-called "Carex salina group" form an important part of the circumpolar coastal ecosystems, but belong to one such critical group of taxa. Egorova (1999) recognized this group as a separate 
section, Temnemis (Raf.) V.I.Krecz. The taxonomy of this section is controversial; different authors have accepted from six (Elven et al., 2005) to 15 (Egorova, 1999) species. Elven et al. (2005) suggested that all species of this section belong to a single large "biological" species, bridged by extensive gene flow. In addition, vast hybridization between sect. Temnemis and some mire and wetland species from the closely related section Phacocystis Dumort. (for example with C. aquatilis Wahl. or C. nigra (L.) Reichard) has also been suspected. This led Standley et al. (2002) to merge these two sections into the single section Phacocystis s.l.

In northwestern Russia, four species are traditionally accepted in the $C$. salina group (summarized in Egorova, 1999): C. paleacea Schreb. ex Wahlenb., C. recta Boott, C. salina Wahlenb. and C. subspathacea Wormsk. All of them are classified as belonging to the rare species of Karelia (Kravchenko et al., 2000), and C. paleacea and C. salina are listed as endangered in the Red Book of the Murmansk region (Konstantinova et al., 2003).

The taxonomy of the $C$. salina group has been wellstudied in North America. These studies included meiosis in experimental hybrids, pollen fertility, and morphology (Cayouette and Morisset, 1985), and allozyme variation and foliar anatomy (Standley, 1990). Carex paleacea and C. subspathacea appeared to be the most well-defined ("pure") species, whereas C. salina was concluded to represent a stabilized hybrid between them. Carex recta turned out to be the most problematic taxon. In North America, it was hypothesized to consist of several entities derived from more or less stabilized crosses between one species from section Temnemis and one from section Phacocystis, namely $C$. paleacea and C. aquatilis (C. recta s. str.; Cayouette and Morisset, 1985; Standley, 1990).

However, morphological studies in northwestern Europe have led to an alternative hypothesis on the origin of C. salina and C. recta. Egorova (1999) suggested that the Russian material referred to $C$. salina is derived from C. recta $\times$ subspathacea. There are also suggestions that a part of the northwestern European material referred to $C$. recta could be derived from C. nigra $\times$ paleacea (C. vacillans Drejer ex Hartman, Faulkner, 1973) or C. aquatilis $\times$ salina (C. halophila sensu auct. norv., non F.Nyl., Elven et al., 2005). Thus, it is possible that the taxonomic situation, including delimitation, characterization, and origin of the taxa, may be different in Europe and North America. More detailed investigations of European material are therefore needed.

It is clear that the conservation policy for rare species strictly depends on their taxonomic status. For example, in the case of species with recent hybrid origin, the best way can be to protect the parental species. However, clarification of the taxonomic status and testing of hybrid hypotheses are difficult without using molecular markers. This is especially true for the group under consideration because common evidence of hybrid origin such as low pollen fertility and intermediate morphology can hardly be used in Carex (Cayouette and Morisset, 1985; Egorova, 1999; Faulkner, 1972; Standley, 1990). For example, high phenotypic plasticity was reported in all members of the group based on common garden experiments (Cayouette and Morisset, 1985; Faulkner, 1972), and the pollen fertility has been shown to be very variable even in supposedly "pure" species of this group (Egorova, 1999).

Here we address the taxonomic situation in the C. salina group in the Kola peninsula with emphasis on the taxa of supposed hybrid origin (C. salina and $C$. recta coll.). We use amplified fragment length polymorphism (AFLP), a high resolution molecular method which is efficient for identifying interspecific hybrids (e.g., Kapralov et al., 2006). We combined molecular analysis with morphological analysis, an approach shown to be a powerful tool for testing hypotheses in complex low-level taxonomy (Hansen et al., 2000; Shipunov et al., 2004).

\section{Materials and Methods}

\section{Sampling}

In 2005 and 2006 a total of 92 individuals were sampled from 28 sites, ranging from one to five individuals from each site (Fig. 1; Table 1). Several taxa co-occurred in some of the sites. Because the plants are rhizomatous and capable to form large clones, the plants were collected $5 \mathrm{~m}$ apart to minimize resampling of the same clone. The plants were selected to represent the morphological variation observed at each site. Leaf samples from most plants were dried separately in silica gel for DNA analysis, and the remains of each plant was pressed as a voucher for morphological analysis. The voucher specimens were later determined by R. Elven, and his tentative determinations are used throughout this paper. The plants were referred to C. salina, C. recta coll., C. subspathacea and C. paleacea, and three putative hybrid combinations (Table 1). Thus, our sample included all European Russian species of section Temnemis sensu Egorova, 1999. In addition, we collected C. aquatilis from section Phacocystis (sensu Egorova, 1999) because it has been suggested to be involved in extensive hybridization with the $C$. salina group. We also included a collection of $C$. subspathacea from the Svalbard archipelago. Voucher specimens from each site are deposited at the Botanical Museum in Oslo $(\mathrm{O})$. 


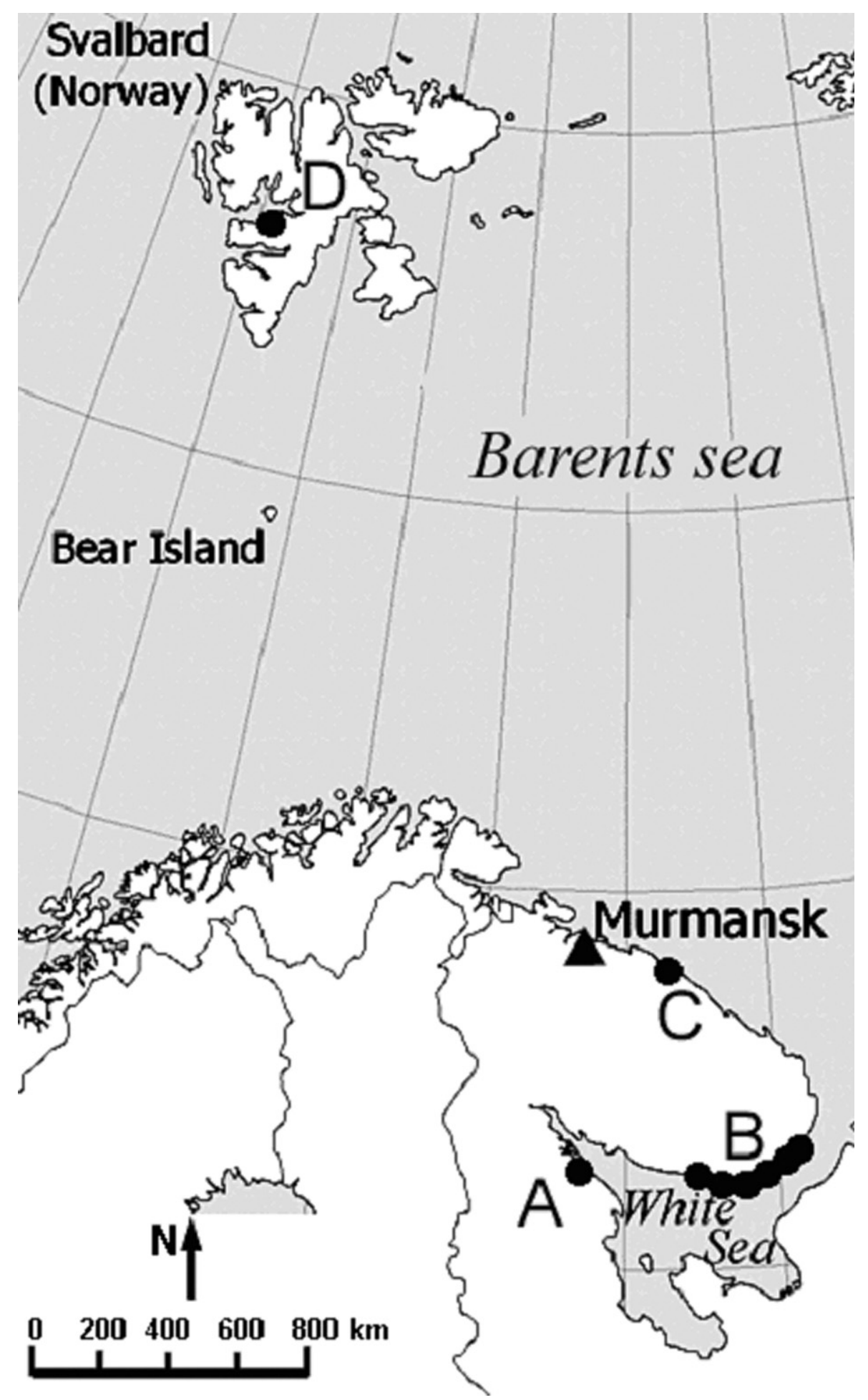

Fig. 1. The four geographic regions with the investigated sites of Carex (cf. Table 1). A - Karelia, Loukhi region, shore of the White Sea, Kandalaksha Gulf, Russia, B - Terskij seashore, Kola Peninsula, between the rivers Varzuga and Ponoj, Russia, C - Murmansk region, Severomorsk district, Kola Peninsula, Barents Sea shore, Russia, D - Spitsbergen, Svalbard, Norway.

\section{DNA isolation and AFLP}

DNA was extracted from dried leaf material using the CTAB method following Schönswetter et al. (2002), except that the samples were frozen for $15 \mathrm{~min}$ at $-80^{\circ} \mathrm{C}$ after adding CTAB buffer. We used silica gel samples from all but five of the sites. For these five sites, silica gel samples were not available and we used leaves taken from the voucher specimens (Table 1); we found no significant differences between the results of AFLP 
Table 1. Collection data for Carex samples analysed in this study. Tentative determinations were made by R. Elven prior to the molecular analysis

\begin{tabular}{llll}
\hline $\begin{array}{l}\text { Site } \\
\text { no. }\end{array}$ & Geographic origin (cf. Fig. 1) & Date & $\begin{array}{l}\text { Collectors }^{\mathrm{a}} \\
\begin{array}{l}\text { No. } \\
\text { of } \\
\text { plants }\end{array}\end{array}$ \\
\hline
\end{tabular}

A: Karelia, Loukhi region, shore of the White Sea, Kandalaksha Gulf, Russia

53 Sidorovyh Ostrova Arch., Cherepakha Isl., seashore, 66 ${ }^{\circ} \quad 04.08 .05$ $21^{\prime} \mathrm{N}, 33^{\circ} 52^{\prime} \mathrm{E}$

73 Krasnaya Bay, between littoral zone and birch forest, $66^{\circ}$ $26^{\prime} \mathrm{N}, 33^{\circ} 35^{\prime} \mathrm{E}$

54 Sidorov Isl., NE shore, $66^{\circ} 21^{\prime} \mathrm{N}, 33^{\circ} 49^{\prime} \mathrm{E}$

55 Chupa Bay, Cape Ivanov Navolok, seashore, $300 \mathrm{~m}$ SE of the Ivan'kov Isl., $66^{\circ} 20^{\prime} \mathrm{N}, 33^{\circ} 40^{\prime} \mathrm{E}$

56 Chupa Bay, Bol'shoj Gorelyhj Isl., SE shore, $66^{\circ} 18^{\prime} \mathrm{N}$, $33^{\circ} 36^{\prime} \mathrm{E}$

71 Kem-Ludskij Arch., Asafij Isl., central bay of the S shore, $66^{\circ} 25^{\prime} \mathrm{N}, 33^{\circ} 50^{\prime} \mathrm{E}$

Chupa Bay, $100 \mathrm{~m}$ E of the vil. Nizhnyaya Pulonga, seashore

61 Chupa Bay, $3 \mathrm{~km}$ SE of the vil. Nizhnyaya Pulonga, seashore, $66^{\circ} 17^{\prime} \mathrm{N}, 33^{\circ} 13^{\prime} \mathrm{E}$ Chupa Bay, Bol'shoj Gorelyhj Isl., E shore, $66^{\circ} 19^{\prime} \mathrm{N}, 33^{\circ}$ $36^{\prime} \mathrm{E}$

60 Medvezh'ya Bay, Pryaostrov Isl., 66 21 $21^{\prime} \mathrm{N}, 33^{\circ} 36^{\prime} \mathrm{E}$

62 Chupa Bay, $3 \mathrm{~km} \mathrm{SE}$ of the vil. Nizhnyaya Pulonga, seashore, $66^{\circ} 17^{\prime} \mathrm{N}, 33^{\circ} 13^{\prime} \mathrm{E}$ Chupa Bay, central part of the vil. Nizhnyaya Pulonga, seashore, $66^{\circ} 18^{\prime} \mathrm{N}, 33^{\circ} 17^{\prime} \mathrm{E}$ Chupa Bay, $2.5 \mathrm{~km}$ E of the vil. Nizhnyaya Pulonga, seashore, $66^{\circ} 18^{\prime} \mathrm{N}, 33^{\circ} 20^{\prime} \mathrm{E}$ Chupa Bay, Bol'shoj Gorelyhj Isl., E shore, $66^{\circ} 19^{\prime} \mathrm{N}, 33^{\circ}$ $39^{\prime} \mathrm{E}$

\begin{tabular}{|c|c|c|c|}
\hline 11.08 .05 & $\mathrm{OK}, \mathrm{PB}$ & $1^{c}$ & C. paleacea \\
\hline 04.08 .05 & $\mathrm{DM}, \mathrm{AV}$ & 5 & C. salina \\
\hline 05.08 .05 & $\mathrm{DM}, \mathrm{AV}$ & 2 & C. salina \\
\hline 07.08 .05 & $\mathrm{DM}, \mathrm{AV}$ & 1 & C. aquatilis \\
\hline 10.08 .05 & $\mathrm{AV}, \mathrm{AS}$ & 3 & C. recta \\
\hline 12.08 .05 & EA & 4 & C. recta \\
\hline 04.08 .05 & $\mathrm{OK}$ & 4 & C. halophila \\
\hline 07.08 .05 & $\mathrm{DM}, \mathrm{AV}$ & 2 & C. aquatilis $\times$ salina \\
\hline 09.08 .05 & OK, LM & $1^{\mathrm{c}}$ & C. aquatilis $\times$ salina \\
\hline 04.08 .05 & EA & $5^{c}$ & C. aquatilis $\times$ salina \\
\hline 04.08 .05 & $\mathrm{OK}, \mathrm{EA}$ & $1^{c}$ & C. aquatilis $\times$ salina \\
\hline 06.08 .05 & OK & $1^{\mathrm{c}}$ & C. aquatilis $\times$ salina \\
\hline 07.08 .05 & DM, AV & 1 & C. aquatilis $\times$ salina \\
\hline
\end{tabular}

B: Terskij seashore (Kola peninsula, shore of the White Sea between rivers Varzuga and Ponoj), Russia

310 NW part of Bol'shaya Bab'ya Bay, $24 \mathrm{~km} \mathrm{SW}$ of the vil. Sosnovka, coastal marsh, $66^{\circ} 23,4^{\prime} \mathrm{N}, 40^{\circ} 18,5^{\prime} \mathrm{E}$

308 W shore of the riv. Bol'shaya Kumzhevaya, $300 \mathrm{~m}$ upriver, coastal marsh, $66^{\circ} 12,5^{\prime} \mathrm{N}, 39^{\circ} 43,7^{\prime} \mathrm{E}$

311 Stream estuary, $1.5 \mathrm{~km}$ SWS of the vil. Sosnovka, coastal marsh, $66^{\circ} 29,6^{\prime} \mathrm{N}, 40^{\circ} 74,3^{\prime} \mathrm{E}$

303 Sandy shore of stream, $5.5 \mathrm{~km}$ ESE of the riv. Varzuga estuary, $66^{\circ} 15,1^{\prime} \mathrm{N}, 37^{\circ} 04,2^{\prime} \mathrm{E}$

306 Stream estuary $1.5 \mathrm{~km}$ E of the riv. Strel'na estuary, coastal marsh, $66^{\circ} 03,7^{\prime} \mathrm{N}, 38^{\circ} 41,5^{\prime} \mathrm{E}$

304 Sandy shore of stream, $5 \mathrm{~km}$ ESE of the riv. Varzuga estuary, $66^{\circ} 15,25^{\prime} \mathrm{N}, 37^{\circ} 03,54^{\prime} \mathrm{E}$

305 E shore of stream, $2 \mathrm{~km} \mathrm{NW}$ of the vil. Tetrino, coastal marsh, $66^{\circ} 04,2^{\prime} \mathrm{N}, 38^{\circ} 12,5^{\prime} \mathrm{E}$

307 S shore of former river-bed of the riv. Chapomka, $3 \mathrm{~km} \mathrm{E}$ of the vil. Chapoma, coastal marsh, $66^{\circ} 06,5^{\prime} \mathrm{N}, 38^{\circ} 55,7^{\prime}$ E

\begin{tabular}{llr}
22.08 .06 & PV, LA, & 5 \\
\multirow{2}{*}{23.08 .06} & YK & \\
& PV, LA, & 5 \\
28.08 .06 & YK & \\
& PV, LA, & 3 \\
& YK & \\
13.08 .06 & PV, LA, & 4 \\
& YK & \\
18.08 .06 & PV, LA, & 5 \\
& YK & \\
13.08 .06 & PV, LA, & 5 \\
& YK & \\
17.08 .06 & PV, LA, & 5 \\
& YK & \\
19.08 .06 & PV, LA, & 5 \\
& YK \\
24.08 .06 & PV, LA, & 3 \\
& YK
\end{tabular}

C. salina

C. recta

C. subspathacea

C. aquatilis + C. recta

C. aquatilis + C. recta

C. aquatilis $+C$. paleacea $\times$ recta C. aquatilis

C. salina $+C$. halophila

309 W shore of the riv. Pulonga, $500 \mathrm{~m}$ upriver, coastal marsh, $66^{\circ} 15,7^{\prime} \mathrm{N}, 39^{\circ} 59,0^{\prime} \mathrm{E}$

C: Murmansk region, Severomorsk district, Kola Peninsula, Barents Sea shore, Russia

\begin{tabular}{|c|c|c|c|}
\hline 51 & $\begin{array}{l}\text { W shore of Gavrilovskaya Bay, } 10 \mathrm{~km} \mathrm{NE} \text { of the vil. } \\
\text { Dal'niye Zelentsy, } 69^{\circ} 04^{\prime} \mathrm{N}, 35^{\circ} 22^{\prime} \mathrm{E}\end{array}$ & 27.07 .05 & $\begin{array}{l}\text { OK, DM, } \\
\text { PV }\end{array}$ \\
\hline 52 & $\begin{array}{l}\text { E shore of Gavrilovskaya Bay, } 10 \mathrm{~km} \mathrm{NE} \text { of the vil. } \\
\text { Dal'niye Zelentsy, } 69^{\circ} 04^{\prime} \mathrm{N}, 35^{\circ} 22^{\prime} \mathrm{E}\end{array}$ & 27.07 .05 & $\begin{array}{l}\text { OK, DM, } \\
\text { PV }\end{array}$ \\
\hline
\end{tabular}

1
nigra $\times$ subspathacea C. halophila

C. salina + C. nigra

$\times$ subspathacea

\section{C. salina $+C$.}


Table 1. (continued)

\begin{tabular}{|c|c|c|c|c|c|}
\hline $\begin{array}{l}\text { Site } \\
\text { no. }\end{array}$ & Geographic origin (cf. Fig. 1) & Date & Collectors ${ }^{\mathrm{a}}$ & $\begin{array}{l}\text { No. } \\
\text { of } \\
\text { plants }\end{array}$ & Taxon $^{\mathrm{b}}$ \\
\hline 301 & $\begin{array}{l}\text { Gavrilovskije Ostrova Arch., isl. Bol'shoj Gavrilovskij, } \\
6 \mathrm{~km} \text { NE of the vil. Dal'niye Zelentsy, wet rocks, } 69^{\circ} 10,3^{\prime} \\
\mathrm{N}, 35^{\circ} 57,0^{\prime} \mathrm{E}\end{array}$ & 06.08 .06 & $\begin{array}{l}\text { PV, LA, } \\
\text { DS }\end{array}$ & 5 & C. aquatilis $\times$ salina \\
\hline 302 & $\begin{array}{l}\text { Gavrilovskije Ostrova Arch., isl. Bol'shoj Gavrilovskij, } \\
6 \mathrm{~km} \text { NE of the vil. Dal'niye Zelentsy, stream shore, } 69^{\circ} \\
10,3^{\prime} \mathrm{N}, 35^{\circ} 57,0^{\prime} \mathrm{E}\end{array}$ & 06.08 .06 & PV & 5 & C. aquatilis $\times$ salina \\
\hline \multicolumn{6}{|c|}{ D: Svalbard, Spitsbergen, Norway } \\
\hline 312 & $\begin{array}{l}\text { Bolternosa Mtn., Adventdalen valley, wet marsh, } 78^{\circ} 20^{\prime} \\
\mathrm{N}, 17^{\circ} 00^{\prime} \mathrm{E}\end{array}$ & 07.08 .06 & $\mathrm{KW}, \mathrm{TP}$ & 5 & C. subspathacea \\
\hline
\end{tabular}

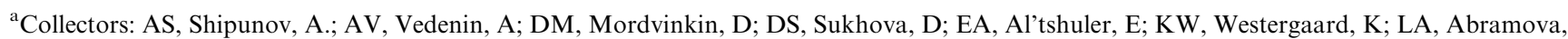
L; ML, Lyovina, M; OK, Kudina, O; PB, Burchits, P; PV, Volkova, P; TP, Presto, T.; YS, Kosenko, Ya; VL, Loginov, V; VV, Vasenina, V.

${ }^{\mathrm{b}}$ Several taxa occurred together in some sites.

${ }^{\mathrm{c}}$ DNA was extracted from pressed plants (tested for DNA quality; see text).

analysis of these two types of samples taken from the same individual plants (see also below). We extracted 19 randomly selected plants twice. These duplicates, as well as negative controls, were included to test for reproducibility and contamination (cf. Bonin et al., 2004).

AFLP analysis was performed according to Gaudeul et al. (2000), except that the reaction volumes in the polymerase chain reaction (PCR) were reduced by $50 \%$ and that the preselective PCR-products were diluted ten times. Twenty-four primer pair combinations were tested on eight plants representing several taxa. AFLP profiles with many polymorphic markers and well separated fragments were selected. A second primer test was carried out using five primer pair combinations, chosen from the first primer test, on 32 plants from several taxa. Finally, three of the primer pair combinations were chosen, which produced a manageable number of fragments that were well separated. The final AFLP analysis was carried out with the following primer pair combinations: EcoRI AGA (6FAM)-MseI CTG, EcoRI ATC (VIC)-MseI CTA, and EcoRI AAC (NED)-MseI CAT. For each individual, $2.0 \mu 1$ 6-FAM, $2.0 \mu \mathrm{l}$ VIC and $3.0 \mu \mathrm{l}$ NED labeled selective PCR products were mixed with $11.7 \mu$ formamide and $0.3 \mu \mathrm{l}$ GeneScan ROX 500 size standard and run on an ABI 3100 sequencer (Applied Biosystems).

Raw data were analyzed using the ABI prism GeneScan version 3.7 analysis software (Applied Biosystems) and imported for scoring into Genographer (version 1.6. available at http://hordeum.oscs.montana.edu/genographer/). Fragments in the size range of $70-500 \mathrm{bp}$ were scored as present or absent. The average reproducibility, calculated as the average proportion of correctly reproduced bands over all replicates (Bonin et al., 2004), was $97 \%$ for the three primer pair combinations. There was no significant difference in average proportion of correctly reproduced bands over herbarium and silica dried samples taken from the same plant (12 pairs of samples tested) and over all replicates (t-test: $p=0.6$ ).

\section{Morphometry}

We initially explored the variation in a number of characters that previously had been used to separate the taxa (Altshuler and Shipunov, 2005). A final set of eight primary and two derived characters were used for the analysis (Table 2). The morphological measurements were performed on the field-collected material.

\section{Data analyses}

Principal coordinate analysis (PCO) was used to visualize pair-wise similarities between the AFLP multilocus phenotypes, using both the simple matching and Dice similarity coefficients. The Dice coefficient takes into account only similarity in presence of fragments, while the simple matching coefficient takes into account both presence and absence of fragments. PCO analyses were executed in the R 2.1.1 environment for statistical computing (R Development Core Team, 2004).

Analyses of molecular variance (AMOVA) were computed with the software Arlequin 3.0.1 (Schneider et al., 1997) to quantify genetic differentiation at different hierarchical levels. The significance levels of the variances were estimated in a permutation test with 10000 permutations.

The taxonomical structure was also examined by genetic mixture analysis using the software STRUCTURE 2.1 (Pritchard et al., 2000) with a model-based clustering method using Markov Chain Monte Carlo 
Table 2. Morphological variation in the Carex salina group based on the tentative determinations given in Table 1

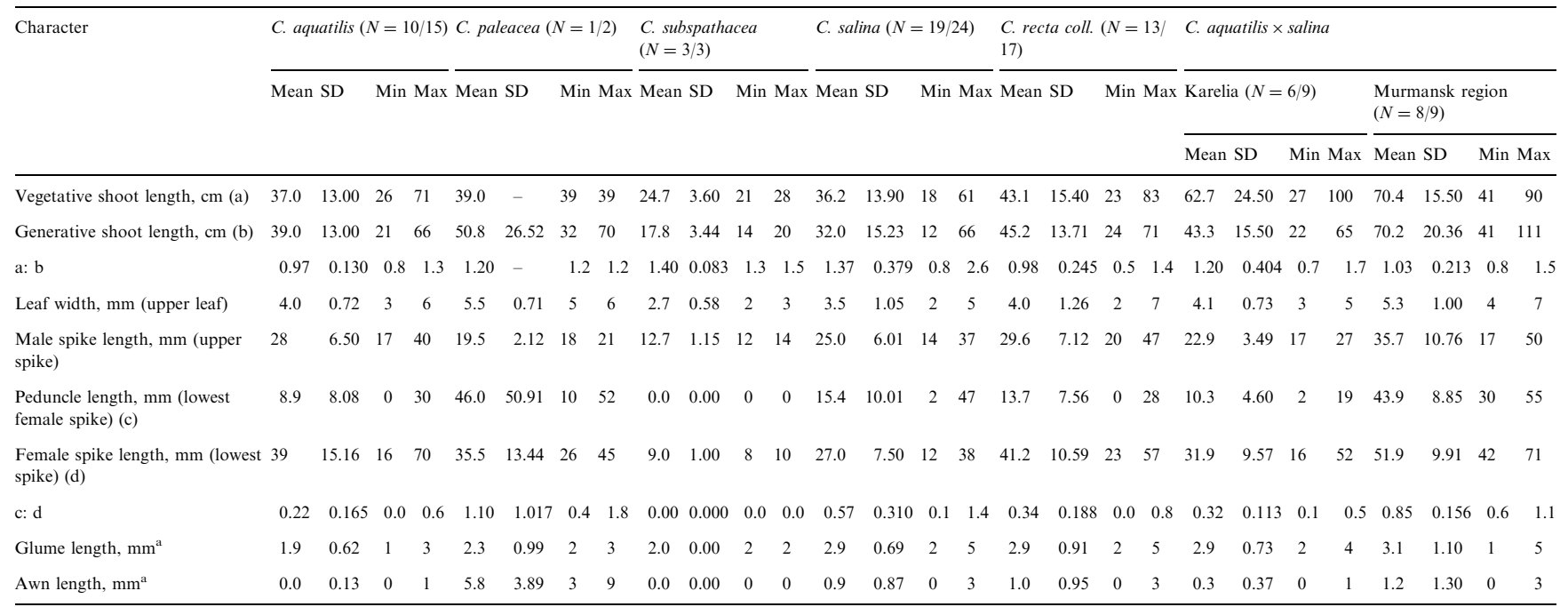

Only plants used for AFLP analysis were included. $N$ - number of plants measured (the first number concerns vegetative shoot length, vegetative shoot length: generative shoot length; the second number (after slash) concerns all other characters). SD - standard deviation.

${ }^{a}$ measured in the middle of the lowest female spike; glume length exclusive awn. 
estimation. In this program it is possible to identify the optimal number of groups $(\mathrm{K})$ by comparing the likelihood of the data estimated in different runs for different numbers of groups. Individuals are assigned (probabilistically) to one of the clusters defined by allele frequencies at each locus. Our data were analyzed at the Bioportal, University of Oslo (http://www.bioporta1.uio.no), with $\mathrm{K}$ ranging from one to 10,10 replicate runs for each $\mathrm{K}$ and a burn-in period of $2 \times 10^{5}$ and $10^{6}$ iterations. The no admixture model and uncorrelated allele frequencies were assumed for the analysis. Similarity coefficients among pairs of Structure runs were calculated according to Rosenberg et al. (2002) using the R-script AFLPdat (Ehrich, 2006).

We performed multilocus assignment tests using AFLPOP (Duchesne and Bernatches, 2002) to test the hypotheses on hybrid origins of plants referred to C. salina, C. recta coll. and C. salina $\times C$. aquatilis. In AFLPOP the differences in frequencies at polymorphic loci are used to assign a specimen to its most probable species or simulated $F_{1}$ and $F_{2}$ hybrids or backcrosses (see Kapralov et al., 2006 for details). Marker frequencies of zero were replaced by $1 /($ sample size +1$)$.

Converting of the output of Genographer to an AFLP data matrix for PCO and generating the input files for Arlequin and STRUCTURE were made with the R-script AFLPdat (Ehrich, 2006).

\section{Results}

\section{AFLP variation}

The AFLP analysis provided 101 polymorphic markers. The PCO plot based on the Dice similarity coefficient (Fig. 2) showed a continuum with the three supposedly "pure" species (C. aquatilis, $C$. subspathacea and $C$. paleacea) at its extreme parts, forming a triangle. Interestingly, the geographically distant Svalbard sample of $C$. subspathacea were placed close together with the Murmansk region plants of this species. The plants referred to $C$. salina were, with three exceptions, positioned between $C$. subspathacea and $C$. paleacea. The plants referred to $C$. recta coll. occupied central positions in the plot but in general intermediately between $C$. aquatilis and C. paleacea, and three plants referred to $C$. paleacea $\times$ recta were situated between their putative parents. Four plants supposed to represent $C$. nigra $\times$ subspathacea were positioned between those referred to $C$. aquatilis and those referred to C. subspathacea. Finally, the plants referred to C. aquatilis $\times$ salina were divided into two distinctly separated groups corresponding to different geographic origins: those from Karelia were placed between C. aquatilis and C. subspathacea while those from Murmansk region were situated more or less between

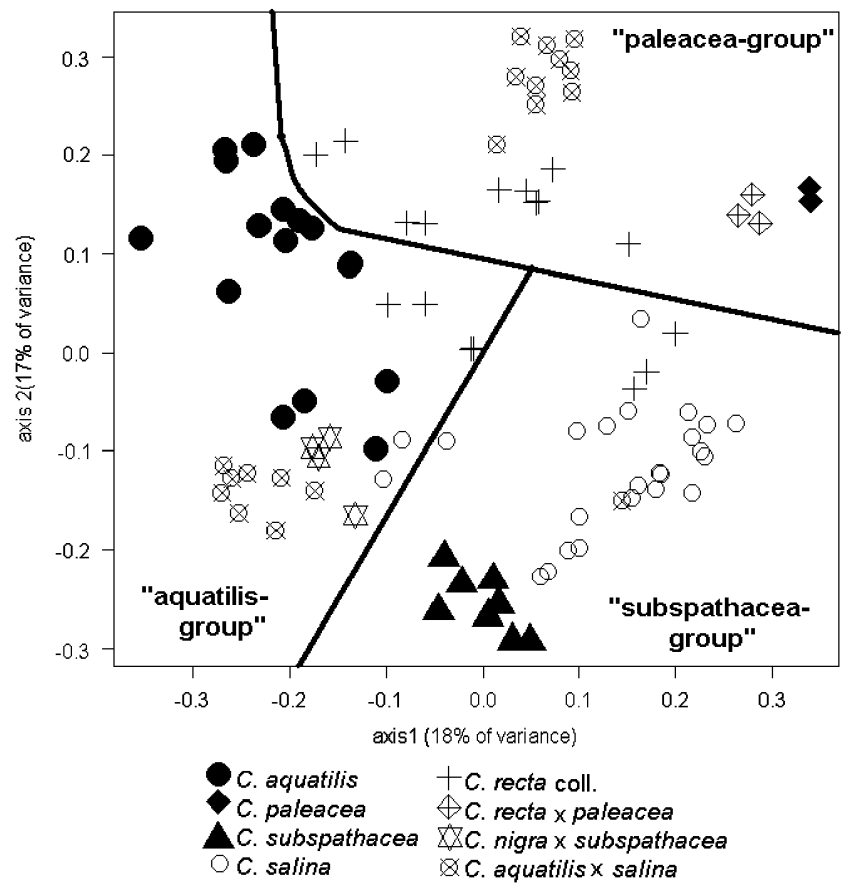

Fig. 2. Principal coordinate analysis (PCO) of all individuals from the 28 collection sites of Carex based on Dice similarity between AFLP multilocus phenotypes. The variation is divided into three parts according to the STRUCTURE analysis. The three supposedly 'pure' species are shown with filled symbols.

C. aquatilis and C. paleacea. The PCO plot based on the simple matching similarity coefficient showed a very similar structure (not shown).

The STRUCTURE analysis clearly revealed three groups, hereafter named after the three supposedly 'pure' species (Figs. 2 and 3). The "paleacea-group" included all plants referred to C. paleacea, C. paleacea $\times$ recta, and C. aquatilis $\times$ salina from Murmansk region, as well as some of the plants referred to C. recta coll. The "subspathacea-group" consisted of all plants referred to $C$. subspathacea and $C$. salina as well as some plants referred to $C$. recta coll. The "aquatilis-group" included all plants referred to C. aquatilis, C. nigra $\times$ subspathacea, C. aquatilis $\times$ salina from Karelia and the remaining plants referred to $C$. recta coll. Thus, the plants referred to $C$. recta coll. were divided among all three STRUCTURE groups.

In the AMOVA analyses (Table 3), the largest proportion of the genetic variation was found within the tentative taxa $(78 \%)$ and within the three supposedly "pure" species $(61 \%)$. There was also a much larger proportion of the genetic variation within the three STRUCTURE groups (78\%) than among them. The proportion of the genetic variation found among the collection sites was almost the same as that within them $(57 \%)$. 
(A)

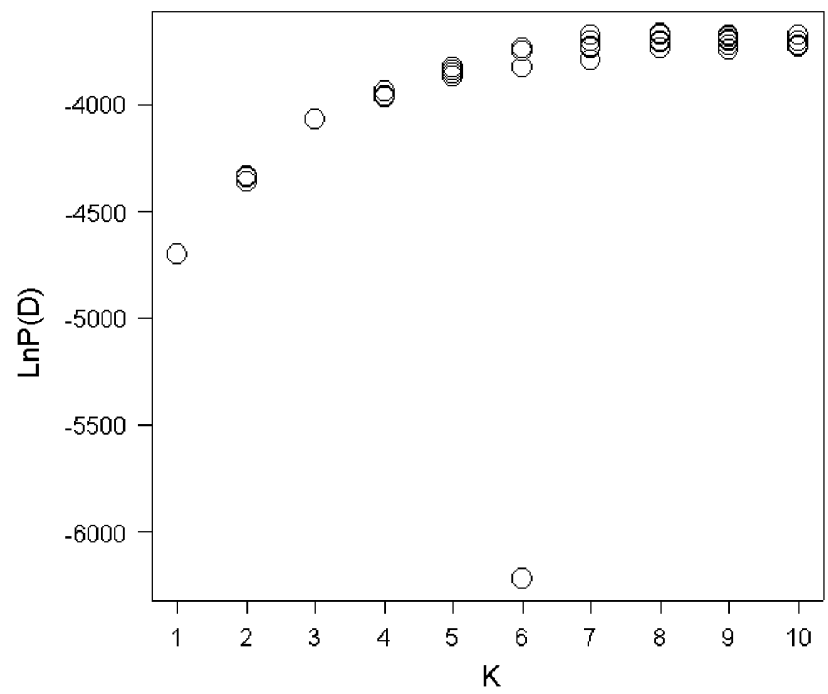

(B)

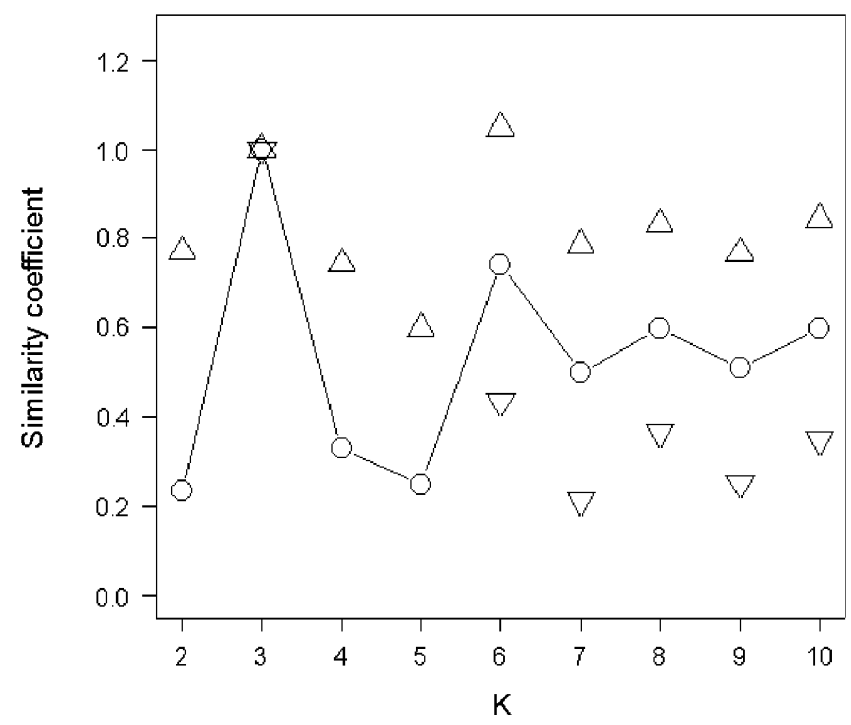

Fig. 3. STRUCTURE analysis of the AFLP data for Carex. (a) Estimated likelihood for values of $\mathrm{K}$ ranging from 1 to 10 . (b) Similarity coefficients of the results from different runs of STRUCTURE calculated according to Rosenberg et al. (2002). Dots represent the average similarity coefficient for the pairwise comparisons among 10 runs and triangles show the standard deviation.

In the assignment tests, an AFLP phenotype was assigned to a group if the likelihood was ten times higher for belonging to this group than to any other group, otherwise the AFLP phenotype was not assigned. The plants referred to $C$. recta coll. were divided into three groups according to the STRUCTURE results (Figs. 2 and 4) before conducting the tests. The first assignment test was performed to find the most likely parents of these three groups. The plants belonging to the "paleacea-group" were either assigned to the simulated C. aquatilis $\times$ paleacea $\mathrm{F}_{1}$ hybrid (two plants) or to
Table 3. Analyses of molecular variance (AMOVA) of the AFLP data for the Carex salina group

\begin{tabular}{ll}
\hline Source of variation & $\begin{array}{l}\% \text { of total } \\
\text { variance }\end{array}$ \\
\hline Among all taxa & 22.3 \\
Within all taxa & 77.7 \\
Among supposedly "pure" species $(C$. & 38.8 \\
aquatilis, C. subspathacea, $C$. paleacea) & \\
Within supposedly "pure” species & 61.2 \\
Among three STRUCTURE groups & 22.0 \\
Within three STRUCTURE groups & 78.0 \\
Among collection sites & 42.8 \\
Within collection sites & 57.2 \\
\hline
\end{tabular}

$\overline{p \text {-values were }<0.001 \text { in all cases (estimated with } 10000 \text { permutations). }}$

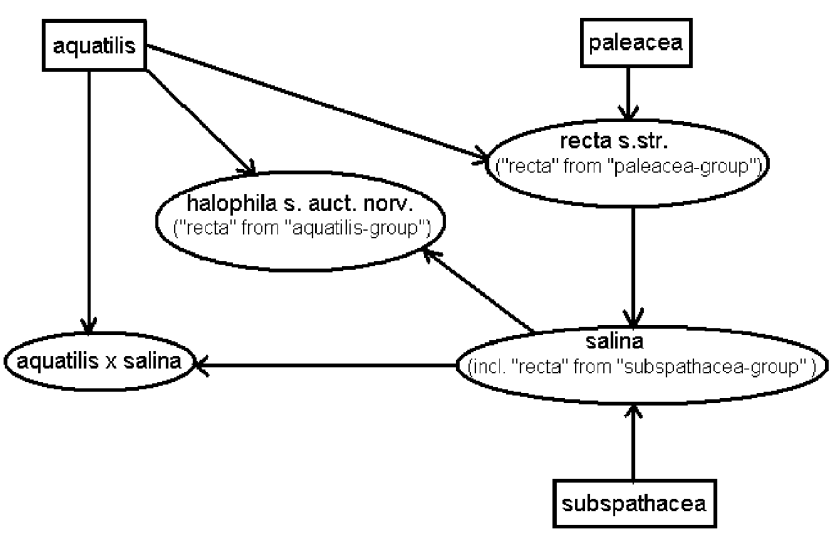

Fig. 4. A tentative hypothesis on the relationships in C. salina group based on AFLPOP analysis of the AFLP data. Arrows indicate hybrid origin. Supposedly "pure" species are shown in rectangles, inferred hybrid combinations in ovals.

C. salina (one plant; five plants were not assigned). The plants belonging to the "subspathacea-group" were assigned to C. salina (two plants; two plants were not assigned). All plants belonging to the "aquatilis-group" were assigned to the simulated $C$. aquatilis $\times$ salina $\mathrm{F}_{1}$ hybrid (three plants).

The second assignment test was conducted to find the most likely parents of the plants referred to C. salina. The majority of these plants were assigned to the simulated C. recta from the "paleacea-group" $\times$ C. subspathacea $\mathrm{F}_{1}$ hybrid (seven plants; nine plants were not assigned). In the last test for the putative C. aquatilis $\times$ C. salina hybrid only two Karelian plants (the other five plants were not allocated) and the majority of plants from the Murmansk region (six plants; three plants were not allocated) were assigned to the simulated $\mathrm{F}_{1}$ hybrid between $C$. aquatilis and C. salina. 


\section{Morphological variation}

The three supposedly "pure" species ( $C$. aquatilis, C. subspathacea and C. paleacea) could be discriminated by a combination of morphological characters (Table 2). The plants referred to $C$. paleacea could be separated from the other two species by presence of long awns on the glumes (mean $5.8 \mathrm{~mm}$ vs. absent in the other taxa) and by its much longer peduncles of the female spikes (46 vs. $0-9 \mathrm{~mm}$ ). The plants referred to C. subspathacea could be separated from those referred to $C$. aquatilis mainly by size characters such as the length of the generative shoots $(178 \pm 34$ vs. $387 \pm 130 \mathrm{~mm}$, respectively), the width of the upper leaf $(2.7 \pm 0.6$ vs. $4.0 \pm 0.7 \mathrm{~mm}$ ) and the length of the lowest female spike $(9 \pm 1$ vs. $39 \pm 15 \mathrm{~mm})$.

The two taxa of proposed hybrid origin (C. salina and C. recta coll.) had extremely variable morphology, and it was not possible to distinguish them from each other or from the supposedly "pure" species with certainty (Table 2). It was neither possible to distinguish the three genetic groups of plants of tentative C. recta coll. found in the STRUCTURE analysis, nor plants tentatively referred to $C$. recta s.str. and $C$. halophila.

The two genetic groups identified within $C$. aquatilis $\times$ salina were only poorly separated morphologically (Table 2). For example, the Karelian plants were somewhat smaller than those from Murmansk (the length of the generative shoot was $433 \pm 155$ vs. $702 \pm 204 \mathrm{~mm}$, respectively) and had shorter peduncles of the female spikes $(10 \pm 5$ vs. $44 \pm 9 \mathrm{~mm})$.

\section{Discussion}

The plants tentatively referred to the three supposedly "pure" species (C. aquatilis, $C$. paleacea and C. subspathacea) formed different extreme parts of the morphological and molecular variation; all other plants analyzed were more or less intermediate between them. This result provides strong evidence for extensive gene flow, supporting the hypothesis that the entire $C$. salina group including $C$. aquatilis acts as a single large biological species in the Kola Peninsula (Elven et al., 2005).

The results of the STRUCTURE analysis and the assignment tests suggest that what is named $C$. recta coll. is heterogeneous and taxonomically polyphyletic (Fig. 4). Our data provide support both for the American (Cayouette and Morisset, 1985; Standley, 1990) hypothesis on the origin of C. recta (i.e., derived from the cross $C$. aquatilis $\times$ paleacea, named $C$. recta s.str.) and the European (Elven et al., 2005) hypothesis (i.e., from the cross $C$. aquatilis $\times$ salina, named C. halophila). In addition, some of the plants we initially referred to as C. recta coll. belonged to the "subspatha- cea-group" in the STRUCTURE analysis of the genetic data, and turned out to be genetically very similar to the plants referred to $C$. salina. However, these three groups of $C$. recta coll. could not be distinguished based on our morphological analysis and do not correspond to the tentative separation between $C$. recta s.str. and C. halophila.

The plants we tentatively referred to as $C$. salina seem to represent a hybrid swarm between $C$. subspathacea and $C$. recta s.str., thus supporting the European hypothesis on the origin of C. salina (Egorova, 1999). However, the difference between the American hypothesis (suggesting that $C$. salina originated from C. paleacea $\times$ subspathacea, see e.g. Standley, 1990) and the European hypotheses is rather subtle, taking into account the supposed origin of $C$. recta s.str. (see above). We therefore conclude that more extended sampling is needed to clarify the origin of the European C. salina.

The plants referred to $C$. salina were as variable morphologically as those referred to $C$. recta s.str. and C. halophila. Egorova (1999) did not find any sharp morphological boundary between $C$. salina, $C$. recta and C. subspathacea in the territory of the former USSR. This was confirmed by our analysis of the Karelian plants, which were intermediate between $C$. salina and C. subspathacea in morphology.

The taxonomic situation in the $C$. salina group in NW Europe seems to be even more complex than that described for North America (Cayouette and Morisset, 1985; Standley, 1990). Firstly, there is sympatric existence of at least two differently named entities of hybrid origin within $C$. recta coll. that cannot be reliably distinguished by morphology. Secondly, a stabilized part of C. salina (which obviously is a taxon of hybrid origin) has probably acted as a parent for another entity of hybrid origin ( $C$. halophila). Moreover, there are probably many instances of backcrosses and hybrids at different levels of stabilization, making the identification of separate plants in this aggregate almost impossible. The morphological and molecular heterogeneity of plants from Karelia and Murmansk that were referred to $C$. salina $\times C$. aquatilis adds to this complexity. It should be noticed that more extensive sampling than we had in this study would likely have revealed even more complex patterns, including additional taxa of unclear status (e.g. C. ramenskii from the Russian Far East). In our opinion, the difference between the taxonomic situations in the investigated group in NW Europe vs. North America reflects the different agricultural and glacial histories of these regions rather than a disagreement on species concepts between European and American systematists (cf. Elven et al., 2005).

Our data for $C$. aquatilis (sect. Phacocystis sensu Egorova, 1999) as well as recent phylogenetic inference based on nuclear and chloroplast DNA sequencing 
(J. Dragon, unpublished) do not support exclusion of C. aquatilis from sect. Temnemis sensu Egorova (1999), but agree with the wide concept of sect. Phacocystis adopted by Standley et al. (2002) and the PAF checklist (Elven et al., 2005). Interestingly, the morphology of the chromosomes of $C$. aquatilis is more similar to that in sect. Temnemis (for example to $C$. paleacea) than to other species of sect. Phacocystis sensu Egorova (Faulkner, 1973).

High levels of genetic variability within taxa, as shown in our data, are typical for some rare plant species (Bruederle, 1999). It has been suggested that rare species may evolve means of maintaining high levels of genetic variability, such as increased outcrossing (Rabinowitz, 1981), which is especially pronounced in the group under consideration where all species appear to hybridize freely.

We argue that conservation efforts in the $C$. salina group in the Kola peninsula should be focused on the two rare "pure" species of the Karelia and Murmansk region - C. paleacea and C. subspathacea (cf. Konstantinova et al., 2003; Kravchenko et al., 2000). The rarity of these two species in the Kola peninsula is confirmed by our own observations: we have observed $C$. subspathacea only once and C. paleacea not at all along $200 \mathrm{~km}$ of coastline (vil. Ust'-Varzuga - vil. Sosnovka), although there are several specimens of both $C$. subspathacea and C. paleacea from this region in the herbaria of Moscow State University (MW) and Komarov Botanical Institute (LE). These species can be easily recognized morphologically (see for example Egorova, 1999), which is important for successful realization of conservation programmes. On the other hand, any attempts to preserve more unstable taxa or hybrid swarms such as C. salina, which currently is listed in the Red Book of the Murmansk region (Konstantinova et al., 2003), will probably be fruitless.

In order to conserve genetic variability, it is necessary to maximize the number of populations preserved due to significant within-species (i.e. among-population) component of diversity (Bruederle, 1999). The other important way is to preserve the habitats where parental species (in our case C. paleacea, C. subspathacea and C. aquatilis) co-occur and hybrids could originate and become established, as a way to preserve the evolutionary process (Pillon et al., 2006). The contact zones between mires (the typical habitat for $C$. aquatilis) and seashores (the typical habitat for $C$. paleacea and C. subspathacea) serve as such habitats.

The most endangered region of the Kola peninsula due to increased human pressure on the seashores is the part of the White Sea shore between the rivers Varzuga and Ponoj. However, the suggestion to establish this shoreline as the National Park "Terskij bereg", proposed in 1994, was rejected in 1996 mainly according to the administration's and locals' opinion. Thus, nowadays in the absence of this National Park we see no real opportunities for the realization of the conservation programmes for the $C$. salina group in the Kola peninsula under conditions of constantly increasing recreation and industry pressure on the seashores.

\section{Acknowledgements}

We thank all the collectors for providing material (cf. Table 1). Most of the material was collected during the White Sea Expedition of Moscow South-West High School, headed by S. Glagolev. A part of the material was collected under the treaty between Moscow SouthWest High School and the Kandalaksha Nature Reserve. We are grateful to V. Mirré for training PV in the molecular laboratory and to D. Ehrich for advice on the statistical analyses. This study was supported by a grant to PV from the Research Council of Norway under the Fellowship Programme for cooperation between Norway and Northwestern Russia. The laboratory costs were covered under the guest researcher programme at the National Centre for Biosystematics (grant 146515/420 from the Research Council of Norway to C. Brochmann and R. Elven).

\section{References}

Altshuler, E.P., Shipunov, A.B., 2005. Morfologicheskaja izmenchivost' osok iz gruppy Carex salina Wahl. (Cyperaceae) na poberezh'je Belogo morja. Vestnik VOOP 10, 1-6 (in Russian).

Bonin, A., Bellemain, E., Eidesen, P.B., Pompanon, F., Brochmann, C., Taberlet, P., 2004. How to track and assess genotyping errors in population genetics studies. Mol. Ecol. 13, 3261-3273.

Bruederle, L.P., 1999. Genetic differentiation of geographically marginal populations in Carex mitchelliana (Cyperaceae): implications for conservation. J. Torrey Bot. Soc. 126, 1-8.

Cayouette, J., Morisset, P., 1985. Chromosome studies on natural hybrids between maritime species of Carex (sections Phacocystis and Cryptocarpae) in northeastern North America, and their taxonomic implications. Can. J. Bot. 63, 1957-1982.

Duchesne, P., Bernatches, L., 2002. AFLPOP: a computer program for simulated and real population allocation using AFLP markers. Mol. Ecol. Notes 2, 380-383.

Egorova, T.V., 1999. The sedges (Carex L.) of Russia and adjacent states (within the limits of the former USSR).St.-Petersburg State Chemical-Pharmaceutical Academy. St.-Petersburg \& Missouri Botanical Garden Press, St. Louis.

Ehrich, D., 2006. AFLPdat: a collection of R functions for convenient handling of AFLP data. Mol. Ecol. Notes 6, 603-604.

Elven, R., Murray, D.F., Razzhivin, V.Y., Yurtsev, B.A., 2005. Checklist of the Pan-Arctic Flora (PAF). Vascular Plants, Draft Version. University of Oslo, Oslo. 
Gaudeul, M., Taberlet, P., Till-Bottraud, I., 2000. Genetic diversity in an endangered alpine plant, Eryngium alpinum L. (Apiaceae), inferred from amplified length polymorphism markers. Mol. Ecol. 9, 1625-1637.

Hansen, K.T., Elven, R., Brochmann, C., 2000. Molecules and morphology in concert: tests of some hypotheses in arctic Potentilla (Rosaceae). Am. J. Bot. 87, 1466-1479.

Kapralov, M.V., Gabrielsen, T.M., Sarapultsev, I.E., Brochmann, C., 2006. Genetic enrichment of the arctic clonal plant Saxifraga cernua at its southern periphery via the alpine sexual Saxifraga sibirica. Mol. Ecol. 15, 3401-3411.

Konstantinova, N.A., Korjakin, A.S., Makarova, O.A., 2003. Krasnaja Kniga Murmanskoj oblasti. Knizhnoe izdatelstvo, Murmansk (in Russian).

Kravchenko, A.V., Gnatjuk, E.P., Kuznetsov, O.L., 2000. Rasprostranenije i vstrechaemost' sosudistyh rastenij floristicheskih rajonov Karelii. Petrozavodsk (in Russian).

Faulkner, J.S., 1972. Chromosome studies on Carex sect. Acutae in NW Europe. Bot. J. Linn. Soc. 65, 271-301.

Faulkner, J.S., 1973. Experimental hybridisation of NW European species in Carex sect. Acutae (Cyperaceae). Bot. J. Linn. Soc. 67, 233-253.

Pillon, Y., Fay, M.F., Shipunov, A.B., Chase, M.W., 2006. Species diversity versus phylogenetic diversity: a practical study in the taxonomically difficult genus Dactylorhiza (Orchidaceae). Biol. Conserv. 129, 4-13.

Pritchard, J.K., Stephens, M., Donnely, P.J., 2000. Inference of population structure using multilocus genotype data. Genetics 155, 945-959.
R Development Core Team, 2004. R: a language and environment for statistical computing. R Foundation for Statistical Computing, Vienna.

Rabinowitz, D., 1981. Seven forms of rarity. In: Synge, H. (Ed.), The Biological Aspects of Rare Plant Conservation. Wiley, New York, pp. 205-217.

Rieseberg, L.H., Gerber, D., 1995. Hybridization in the Catalina Island mountain mahogany (Cercocarpus traskiae): RAPD evidence. Conserv. Biol. 9, 199-203.

Rosenberg, N.A., Pritchard, J.K., Weber, J.L., Cann, H.M., Kidd, K.K., Zhivotovsky, L.A., Feldman, M.V., 2002. Genetic structure of human populations. Science 298, 2381-2385.

Schneider, S., Kueffer, J., Roessli, D., Excoffier, L., 1997. Arlequin 2.000: a software for population genetic analysis. Genetics and Biometry Laboratory, University of Geneva, Switzerland.

Shipunov, A.B., Fay, M.F., Pillon, Y., Bateman, R.M., Chase, M.W., 2004. Dactylorhiza (Orchidaceae) in European Russia: combined molecular and morphological analysis. Am. J. Bot. 91, 1419-1427.

Schönswetter, P., Tribsch, A., Barfuss, M., Niklfeld, H., 2002. Several Pleistocene refugia detected in the high alpine plant Phyteuma globulariifolium Sternb. et Hoppe (Campanulaceae) in the European Alps. Mol. Ecol. 11, 2637-2647.

Standley, L., 1990. Allozyme evidence for the hybrid origin of the maritime species Carex salina and Carex recta (Cyperaceae) in Eastern North America. Syst. Bot. 15, 182-191.

Standley, L.A., Cayouette, J., Bruederle, L., 2002. Carex Linnaeus sect. Phacocystis Dumortier//Flora of North America 23. University Press, New York, NY, pp. 379-401. 